\title{
葡萄の一新病害輪斑病の研究
}

\author{
鑄方米彥 \\ 人見㓮
}

\section{A NEW LEAF-BLIGHT DISEASE OF THE GRAPE=VINE}

\author{
By
}

\section{SuehikoI KATA and Tsuyoshi HiTOMI}

\author{
I 緒 言 \\ II 來歴及び分布 \\ III 被害程度 \\ IIII 病 徵
}

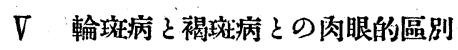

$\mathrm{VI}$ 病原菌 $\mathrm{A}$ 分離培養 $\mathrm{B}$ 接種試驗， C 笴生性 D 形態及び分類上の位置

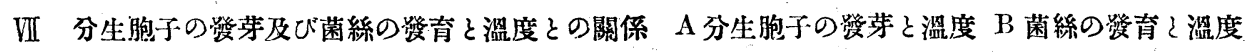

䜣 病原菌の生活史 $\mathrm{A}$ 等吉體侵入 $\mathrm{B}$ 子囊胞子の成熟 $\mathrm{C}$ 分生胞子の生存力

$\mathrm{X}$ 摘 要

圖版說明

英交摘要

\section{一緒六}

葡萄葉の褐斑病（Isariopsis clavispora（B. et C.) Sacc.) は、本邦に於て普通 に栽培され走る甲州葡萄・キャンベルスアーリ・デラウェア等の葉に、褐色の斑 點を生じ落葉時期を早からしめ、被害尠からざる病害にして、栽培家及び植物 病理學者間には周知のものなり。而して余等が述へむこする輸斑病は、前記》 褐斑病に類似する徵候を呈し、この兩者は㢈々混同されをるすのの如し、然踓 精細に泩意すれば兩者は病徵のみにても甚だ異りたる點あり、又その病原菌は 全然相異る病害なり。 
輪斑病の病斑には鮮かるる輸紋を生ずるを以て褐斑病さ區別せむが篇め本名 を附興し置けり、而して本病は未だ學界に報告されしここなき新病害なるが敌 に余等は病原菌つ形態、生活史等につき研究するこころあり、その大要は果物 月報第208,及び210號 $(1,2)$ に豫報したり、その後之が研究略完了せしを以て竨 に詳報せむこす、本報告を編するに當り農學博士堀正太郎氏に深甚なる謝意を 表せざる可らず、何さなれば博士は既に1914年に本病を發見せられ、輸絞病な る新病名を附し、病原菌をAcrothecium の一種さなしその寫生圖を描き、脂葉 標本を作製しをられ、鑄方の豫報を見て自から博士の研究せられし原標本・竄生 圖を揆惠し種々の示教を览はりたればなり、又九州大學中田敎授にも種々の敎 示を仰济り深く謝するこころなり。

\section{二 來歴及分布}

本病は著者の一人(鑄方)が、犬正十四年八月始めて探集せしものにして、岡 山壯小田郡矢掛町の一葡萄園に栽培せるレデーワシントン種の葉に褐斑病に酷 似する病害を見出し、顯微鏡檢查の結果、從來記載せられしここなき新病害な るここを知り得てるものなり、以爽縣下の主要なる葡萄栽培地を踏查せしに、 甲州䄶には未だ之を發見せざるる、岡山縣に於て最も多く栽培しをるキャンべ ルスアーリ種には殆んご發生を認めざる地方なく、處によりては褐斑病より激。 甚なる被害あり、然踓本病さ褐斑病さは芼く混同されをる事實不確め得たり。

堀農學博士の信書によれば本病は關東地方には最も普通なる病害にして、被 害尠らからずこ云ふ、又著者の一人(鑄方)は昭和四年十月福岡縣新田原の一葡 䕎園にても本病を探集せり。堀博士が本病を始めて探集せられしは1914年なる が故に柜當古より存在せしものなるへく、及本州中北部及び南部に盛んに蔓延 し九州にも存在するを以て、可なり廣く分布しをるものなるべし。

* 1 鑄方末彥 淗萄の新病害 (輪斑病)に就て3-5頁、昭和四年九月

2 鐚方末应同上

7-12頁 昭和四年十一月 


\section{三 被害 程 度}

輪斑病は普通八月頃より發生し九、十月の頃最も旺んに傳染する地以て當時

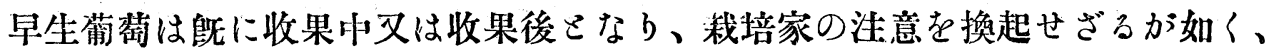
又本病は葉のみを侵し、果實又は枝梢を侵害せざるが故に、直接の加害なきも の〉如く思考されをると踓、余等の敬察によれば決してその被害は輕視すべか らず、何となれば本病の發生激甚なるキャンぶルスアーリ種の如きは、九月下 旬頃既に本病の篇め落葉し、十月に至れば樹上一葉の生葉を止めざるるのお ろ、從つて結果母枝の允實を妨げられ、桎年の結果に重大なる影響あり、され ば葡萄の葉を侵す病害としては露菌病 (Plasmopara viticsla) 褐斑病 (Isar:opsis clarispora）等と共に重大なる病害の一なると信ず。

\section{四病 徽}

本病は七月下旬頃臫にその兆を現すことあるす、多くは八月中下旬に至り盛 んに發生し始め、九月の頃の蔓延最も旺盛にして、十月頃迄その發生を持續 す。

初期の病斑は赫褐色不整形を呈し、褐斑病（Iiariopsis clavispora）に似たる こころあり、時日を經るに從ひ病斑は擴大しはメ゙圓形をなら、葉の表面の部分 には濃淡の色を生じ之がほ心゙同心圆狀をなし鮮かなる輸紋を形成し、裹面は淡 褐色さなる、病斑の大きさは病勞の進行程度によりて大に異り、直俓數 $\mathrm{mm}$ 万 至數 $\mathrm{cm}$ に達す、昭和三年九月に探集せるキャンべルスアーリ種の病葉にては、 最少々の直徑 $5 \mathrm{~mm}$ 普通 $2 \mathrm{~cm}$ 内外最大 $5 \mathrm{~cm}$ 算した 、、擴大したる病斑の内 部は灰褐色乃至浾褐色にして外部虫黑褐色乃至灰褐色を呈す、斯る病斑に法中 心よb 2 乃至 $4 \mathrm{~mm}$ 隔に黑色の同心圆狀の線を以て區劃せられ鮮明なる輸校狀 を生ず之れ本病の特徵なら、病斑面に生ずる輪效線の數は發病後の日數、一葉に

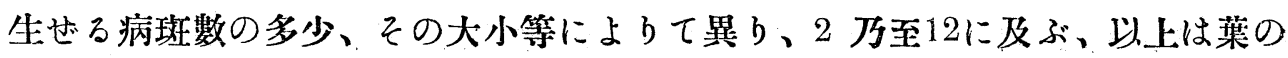


表面に於ける兆候なるが竡面は如何にその病玟は撗大するこも唯淡灰褐色の微 を生じ淡墨を以て暈したるが如さ觀あるのみなり、されご十月下゙句以降に至れ ば白色の徵を密生するを観るものあり、十一月頃にはその上に黑色の小突起点 生ずるここおり、斯くて園内に落下したる枯葉の病斑の竡面(稀には表面)には 十一、三月頃に至れば黑色刺の如き突起をまばらに生ずるすのなり。

一葉に生ずる病斑數は一乃至數十個に及び、病斑數多數なる時は之が㪄め被 害葉は乾燥枯死し、健全葉に比すれば早期に落葉す、從つて被害激甚なる際は 九月頃全葉落下するこさむり。

\section{五 輪斑病と褐斑病との肉眼的區別}

前既に述べたるが如く輪斑病と褐斑病とはその兆候類似し、同一葡萄葉に兩 者を混生するここあり、混同し易さものなるが故に次に兩者の肉眼的區別點在 示し以て參考に供せむ゙。

\begin{tabular}{|c|c|c|}
\hline 要 & $\begin{array}{cc}\text { 輪 } & \text { 玟 } \\
\text { (Acrospermum viticol } & \text { 病 } \\
\text { (c) }\end{array}$ & (Isariopsis clivispora) \\
\hline 1. 病坟D形狀 & 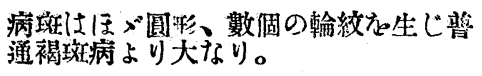 & 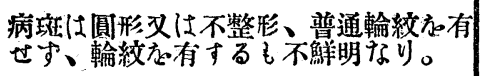 \\
\hline 2. 病斑の色 & 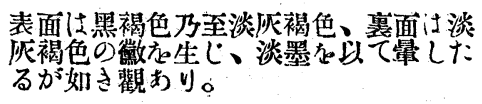 & 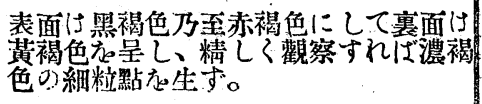 \\
\hline 3. 枯 & 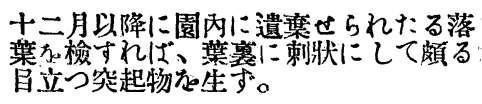 & 之ず見ず。 \\
\hline
\end{tabular}

\section{六病原菌}

本病の病斑の襄面に生ずる淡灰褐色の蚿は病原菌の分生胞子時代にして枯葉 上に生ずる黑色刺樣の突起物は、その子囊殼時代なり。余等は本菌を純粹に培 養し、接種試驗を行ひ病原菌てることを證明し得たり、而して本菌は未だ學界 に報告されしここなき新種なるが故に Lcospermum viticola Ikata n. sP.なる 
新名を附與したり。

是れより先き堀博士は本菌の分坐胞子時代のみを發見せられ、その所屬を Acrothecium sp.さなしをれり、然雖子囊時代は之を發見されざりしこ云ふ(未發 表博士の書信に據る)。

\section{A、分離培養}

余等は本菌の分生胞子及ひ子賈胞子より之が分離培養を行ひしに、多大の困 難を感じたり、然踓操作を反覆せし結果終に扁本培食法により各々純粹に人 工培飬を篇すここを得てり、即ち標準寒天培養基に微量の㽉酸を添加し培養 基を酸性さなし細菌の發育き阻止し本菌を分離したり、本菌は標準寒天培養 基及び馬鈴薯寒天培養基等に於てその發育は極めて遲紘なり、聚落は白色の 菌絲層にして、革質ならず、擔子梗及び分生胞子を形成すれごも子囊殼は之 、を形成せず。

\section{B、接種試驗}

\section{（I）子囊胞子による接種}

昭和三年十二月、上道郡浮出村の葡萄園內にて探集せし病葉を當場內に持 ち歸り樹陰の地面に放置せしに、間もなく多數つ子囊殼を生じ、翌年六月 に至り子囊胞子は成熟したる足以て、同月十五日に子囊殼を破り子囊胞子 を壓出し之を蒸溜水に浮游せしめ接種試驗に供したり。

接種に供したる葡鹤はキャンべルスアーリ種にして、各區十葉宛を撰び每 葉十ケ所づつ接種せり、全その結果を示せば次表の如し。

\begin{tabular}{|c|c|c|c|c|}
\hline 摘 & 接 & 9 & 結 & 果 \\
\hline 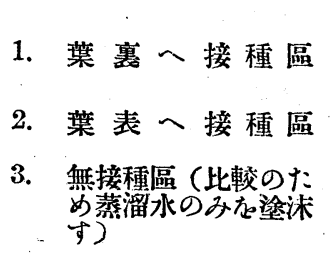 & \multicolumn{4}{|c|}{ 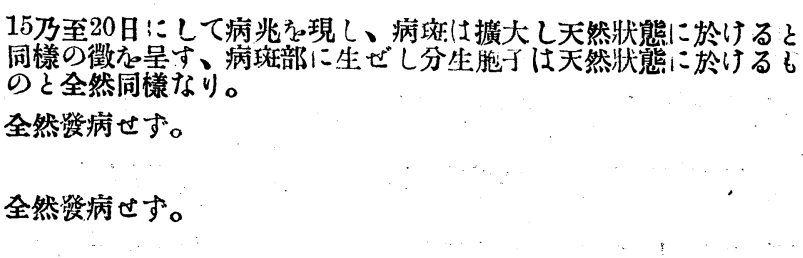 } \\
\hline
\end{tabular}


（II） 分生胞子による接種

標準寒天培養基に培養し、成生されてる分生胞子を蒸溜水に浮游せしめ子 囊胞子の場合己同樣に接㮔せり。

（1）供試品種名不詳(九月五日接種)

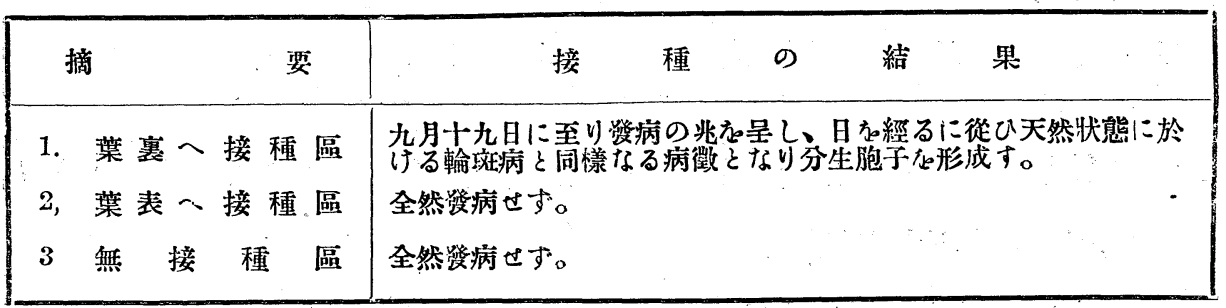

（¿） 供試品種キャンベルスアーリ（九月十二日接種）

\begin{tabular}{|c|c|c|c|c|c|}
\hline 要 & 接 & 種 & Ф & 結 & 果 \\
\hline 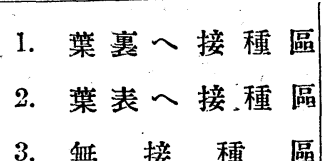 & \multicolumn{5}{|c|}{ 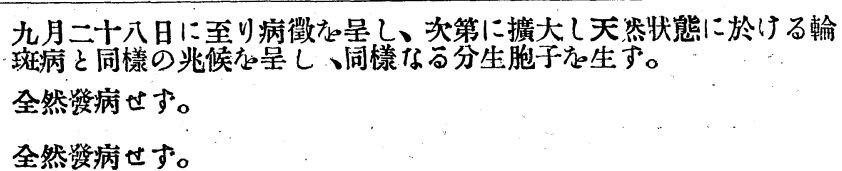 } \\
\hline
\end{tabular}

以上の接種試驗の結果によれば、葡萄の輪斑病は常にその病斑に存在し分生 胞子さ子囊胞子さを生ずる菌. (Acrospermum viticola) の寄生に起因する ここは毫も疑を要せざる事實なり、又分生胞子さ子囊胞子さが同根的關係 あるここす自づから制明すへし。而して本實驗結果の示す處に據れば、本病菌 (Acrospermum viticola) の潜伏期間 (Incubation period) は稍々長く子囊泡 子におるては 15 万至 20 日、分生胞子に於ては15〜6 日なるを知るべく、又 本菌は葉の表面より侵入するここなく常に葉毫より寄主の體內へ侵入するも のなるな知る。

\section{C. 寄生性}

Acrospermum viticola による輪玟病の發生を固場に於て觀るに、アメリカ系 の葡萄（Vitis laburuscana）に限られ、歐洲系（Vitis vinifera）には之を 
見ず、それ故余等は本菌をキャンベルスアーリ種及び甲州種に分生胞子を以て 接種せしに次の結果を得てり。

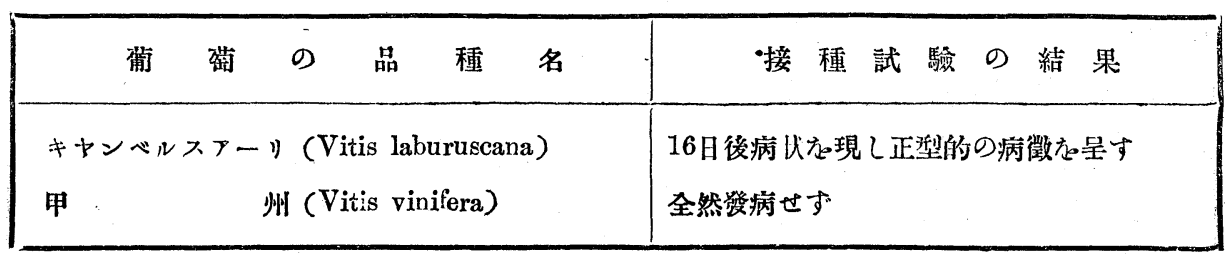

以上の結果によれば本病菌の寄生性は葡萄の種屬によりて異るものつ如し。

\section{D 形態及び其分類上の位置}

本病菌は既に記せるが如く分生胞子(Conidia) こ子囊胞子 (Ascospores) こ を生ず、次にその形態を示さむ。

（I） 分生胞子時代

分生胞子時代は、葡萄葉の病斑の裹面に形成せらる。擔子梗 (Conidiopho $\mathrm{r}(\mathrm{s})$ は病斑面を嶰甸する菌絲より分岐するものにして、等主組織內の菌絲 より直接生ずるここなし、匍匐菌絲より分岐したる擔子梗は或る長さに迄 伸長すれば、その尖端は膨大し、その頂及び周圍に數個の疮狀突起を生じ 之に分生胞子を着生す、同時に膨大部の基部より分岐し第二次の擔子梗を 生ず、このものも或る程度に伸長し、その尖端は膨大して第一次擔子梗に 於けると同榜に分生胞子を着生し、更に之ょり第三次す擔子梗を形成し、 數次に及ぶここあり（插圖第一 A B 參照）

各次の擔子梗の胞子着生部、即ち尖端の膨大部は、一侧に彎曲哭出し瘤狀 を呈するここあり（挿圖第一 B 參照）末端の胞子着生部は然らす、分枝 を生ずるここ稀なるも或る膨大部よりは二個の次代の推子梗を生ずるここ なきにしもあらず(挿圖第一 B 照)。

上述の如く、本菌の擔子梗は、數次に丕りて形成せらる〉か故に、その長 さは極めて不同なり、短きものは $30 \mu$ 内外に過ぎざるも、長きものは $300 \mu$ に達するものあり、各次の擔子梗には普通 1 万至 3 個の隔膜を有す 
るも、之を有せざるここもすり、長き 25 万至 $90 \mu$ あり、幅 3 万至4 色は淡黃褐色なり。

\section{[捚圖第一]Acrospermum viticolx の擔子梗 $飞$ 分生胞子}

A 標準寒天培盖基に成生さるもの(廓大原尺にて示す)

$\mathrm{a}$ 擔子梗に胞子形成の狀 $\mathrm{b}$ 分生胞子

B 天然に成生せるもの（廓大原尺にてて示す）

a 擔子梗の形狀及び扮生胞子着生の狀態

b 分生胞子

c 分生胞于の發芽
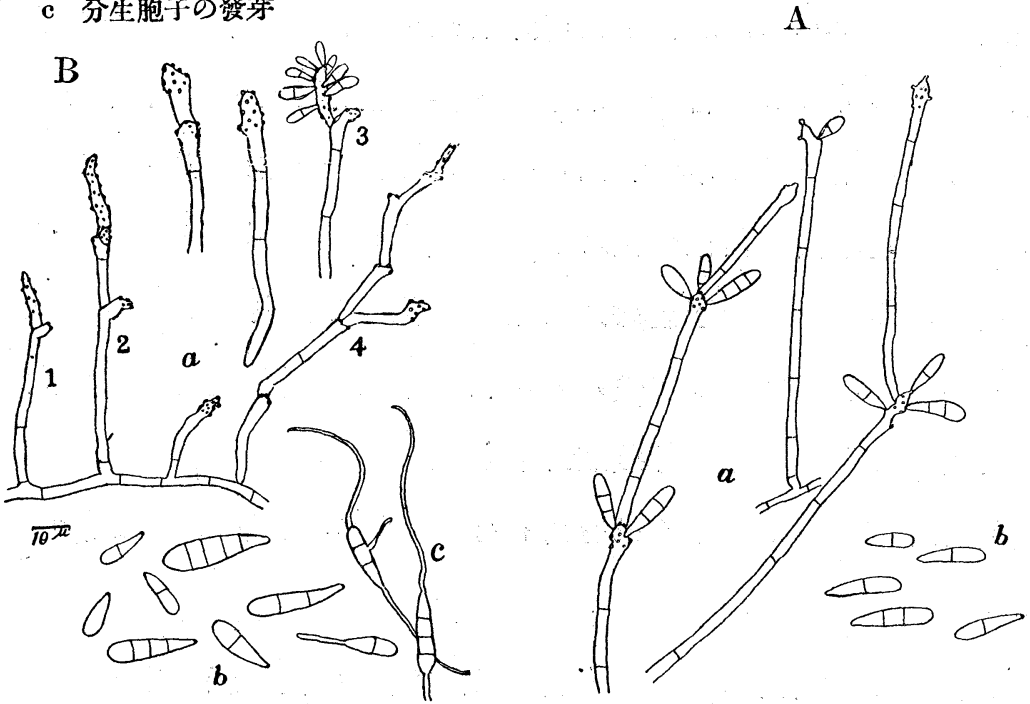

分生胞子（Conidia）は圓筒形乃至椭圓形にして、一端は細く尖り擔子梅 の膨大部より存在する疮狀の突起點に接着し、他端は稍々大きく鈍圆なら 若き分生胞子は隔膜走缺くここあるも普通 1 、2個の隔膜より、老成せるる の虫 $3 、 4$ の隔膜を有するここおり。 分生胞子の大きさは、甚だしき差異すり長さ7.5 万至 $16.3 \mu$ 、幅 2.0 万 至 $6.0 \mu$ あり、100 個の本均は長さ $10.8 \mu$ 、幅 $2.7 \mu$ 、若き胞子は無色 なれごる老成するに從ひ淡黃淡灰色を呈するに至る、蒸溜水中にて容易に 發芽す(挿圖第一 $\mathrm{Bb}, \mathrm{Ab}$ 參照)。

分生胞子の著生狀態は、各次の擔子梗の膨大部に於ける輪生(Verticillatus) にして、一箇所に徽個乃至十個を生す、脫落性にして著生後問るなく落下 
し、擔子梗に疮狀の乫起點を殘す（挿圖第一參照）。

人工培養基(標準寒天)に生也る分生胞子は、その形狀全く天然狀態に於け ると晎らず、然踓その形は稍々小形なり。擔子梗は甚げ長く全長 100万至 $500 \mu$ に達し、各炏の長さ 40 乃至 $100 \mu$ あり、2 乃至 5 個つ隔膜を有 し幅は 3 乃至 $4 \mu$ あり（插圖第一 A 參照)。

\section{（II）子囊胞子時代}

子囊殼 (Perithecia) は、十月以降病葉が末だ枝に着生しをる頃臫に成生 し始むるものあるも、普通は病葉が地面に落下し十一、十二月の頃成生す るものなら、主として葉の童面に生ずるも極めて稀に表面にも生するここ あり、初め病斑面に白色の菌絲を生じ、その中に黑色針頭大の突起をなり て出現す、斯くてこの子囊殼は次第に伸長して四月頃に至れば極度に成長 するものなら、その色は黑色にして恰も葉面に刺を生じたるが如き觀あり 頗る目立つものなり（第一圖版參照）。

子囊殼は群生するここなく孤立疎に生じ、 $1 \mathrm{~cm}$ 本方に 13 乃至 40 個を 算せら。

始め子囊颉は、圓筒形にして基部は太く尖端は稍々細くなり、その內容は 無色の菌絲よりなり表面は黑色にして一種の菌核樣態をなせぎも、その發 青成熟するに伴ひ黑色、一ラ形又は倒棍棒狀に變じ、基部は細く頂は膨大 しその尖端は少しく尖る、病葉の組織內へ埋沒するこさなく全く表面生な b（第一圖版 C 參照）。大さは長さ 900 乃至 $2100 \mu$ 。 幅 196 乃至 $445 \mu$ あり、斷面は扁球形、長徑と短徑との比は 10 對 7 位なり、子囊鼓の壁 膜は稍々堅密なる革質にして、三層よりなる、外首は緻密なる擬柔膜組織 にしてその色は黑褐色乃至淡褐色支呈す、中層は無色線状の菌絲つ集合よ りなり、內層は淡褐色の菌絲よりなる。

子囊（Asci）は、子囊殼の底面より密に叢生し、附均絲を缺く、長き圆筒 形にして膜は薄く、長さ 225 方至 $413 \mu$ 、幅 2.5 万至 $3.5 \mu$ あり、無色な 


\section{b（挿圖第二參照）}

揮圖第二 Acrospermum viticll の于囊及び 囊胞子(廓大)

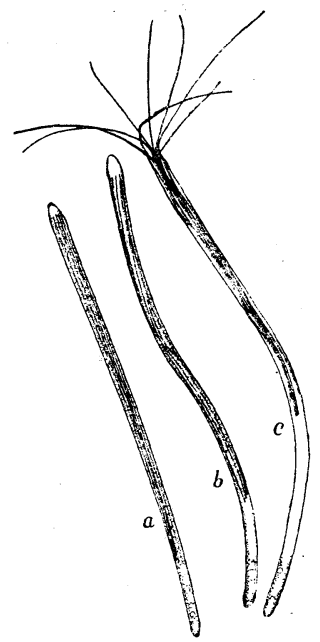

a b 子囊咆子蔵寸る子囊

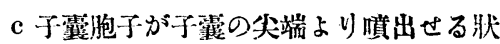

子墨胞子 (Ascospores) は線狀にし て、一子囊に8個宛おり、子囊內に ある胞子は真㨁なれども、水に遭へ

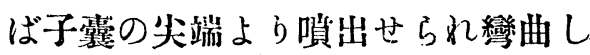
霣形を呈す（挿圖第二及ひ第二圖版 B 參照)、長き 152 乃至 $280 \mu$ 、幅 1 万 至 $2 \mu$ あり、極めて纖細にして無色。 隔膜を有せず。

\section{(III) 分類上の位置}

本病菌の子囊殼は上述の如き形態を 有するね以て、Hysteriales, Acros permaceae Acrospermum 屬に編入す

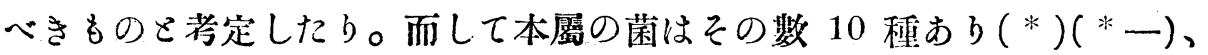
然踓葡䓒に笴生するものなきが故に前記の通りAcrospermum viticola Ikata なる新種名を附與するに至れり。

本菌の分生胞子壯代は前記の如く堀博士は之足 Acrothcoium sp. と せら れしも (来發表)、著者の一人 (鑄方)（*）は堀博士こは關係なく之を Spondyloclatiun 瀜已考定しをれり。

\section{七 分生胞子の發芽及び菌絲の發育と溫度との關係}

本病困の發育こ溫度この關係を明にせさが爲め、行へる實驗成績を示せば下 б)如し。

\section{A. 分生胞子の發芽と溫度}

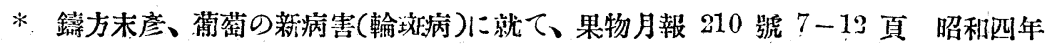

*-A. Engler und K. Prantl ; Die natürlichen Pflanzenfamilien T. I, Abt 1, S. 277-275. 
本菌の分生胞子三十個宛を懸滴し、定溫器に納め二十洔間後その發芽管の長 さを測定せり。

\begin{tabular}{|c|c|}
\hline 溫 & 度 (定 溫 器) \\
\hline $30^{\circ}$ & 19.76 \\
$25^{\circ}$ & 26.56 \\
$20^{\circ}$ & 15.96 \\
$15^{\circ}$ & 7.14 \\
\hline
\end{tabular}

\section{B. 菌絲の發育と溫度}

本菌を標準寒天に扁本培養を行ひ菌層の發育を檢せり。

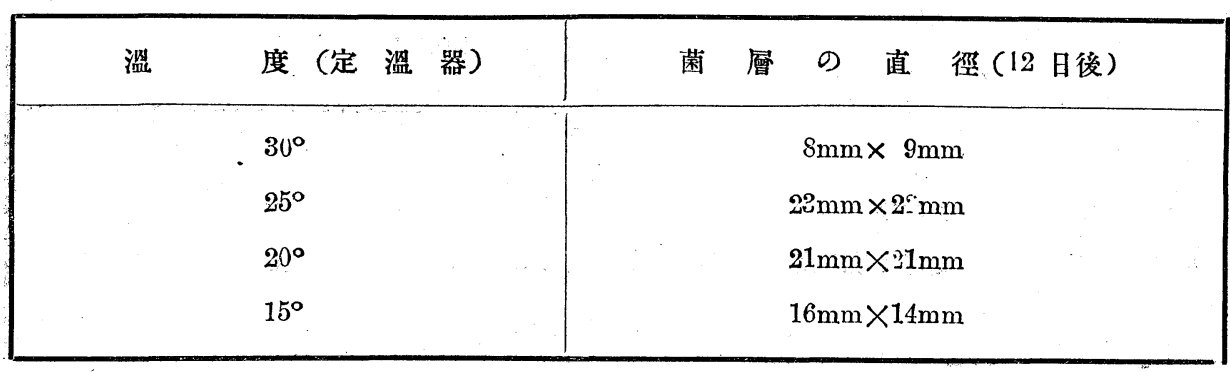

以上の實驗成績によれば本菌の分生胞子の發芽適溫は $25^{\circ} \mathrm{C}$ 附近にあるもの 〉如く、又菌絲の發育は $20^{\circ}-25^{\circ} \mathrm{C}$ にあるもの〉如し。

\section{八 病原菌の生活史}

\section{A. 寄主體侵入法}

本病菌の分生胞子及び子囊胞子を、葡萄の葉に接種したる場合に於て、葉の裏 面より接種すればよく感染するす葉の表面より接種すれば全然威染するここ なし、此の事實は接種試驗の際之を確認し得たるを以て、本菌が葉の裏面に存 在する氣孔より侵入すべきここは想像に難からず、然雖之を確證せむには解 剖學的研究に俟たざる可らず、それ故に余等は本病菌の分生胞子をば葡鸴キ ヤンべルスアーリ種の葉に接種し、3历至5日を䋔て之を固定(Carnoy's fluid)

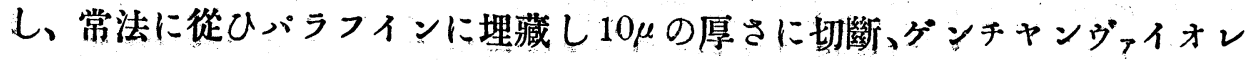


ツト及びェオシンを以て二重染色を行ひ観察するこころありてり。

分生胞子より生せる發芽管は可なり長く寄主の表皮面を匍匐し、その尖端は 氣孔を通過し氣孔腔 (Substomatal cavity) 內に侵入し、間もなく海綿狀組織 を檏成する細胞に到達し、次第に組織内深く侵入すを観る、第二C圖版は接 種後 3 日日に固定せるものなるが、發芽管は氣孔口に於て著しく細くなりて 氮孔を通過し、氣孔腔內に至り少しく膨大しをるを觀るべく、第二D圖版は 接種後5日目に固定せし標本に出現せるものにして、氣孔より侵入せし發芽 管は氣孔腔內にて隔膜否生じ寄主細胞に到達しをれら。而して㸉れの場合に 於ても氣孔以外の場所より侵入しをるを觀たるここなし。

以上の事實によれば本菌の分生胞子より生ずる發芽管は純然てる氣孔侵入性 なり。子囊胞子につきては解剖學的研究を行はざらしも、分生胞子同樣葉裹 のみより感染するが故に、先づ分生胞子さ同樣なる過程を以て侵入するもの と考察して可ならん、果して然らば本病菌は氣孔感染性(Stomatal infection) の菌と云ふべし。

\section{B. 子囊胞子の 成 熟}

本病菌の子囊殼は既に十一・二月の頃成生を始さるも、えが成熟する汽には可 なり長き日月を要す、余等は 1928 年こ 1929 年の十二月に、各々病葉を探 集し、野外に放置し観察するこころあり、全その經過を表示せむ。

\section{（I） 1928-1929 年の観察}

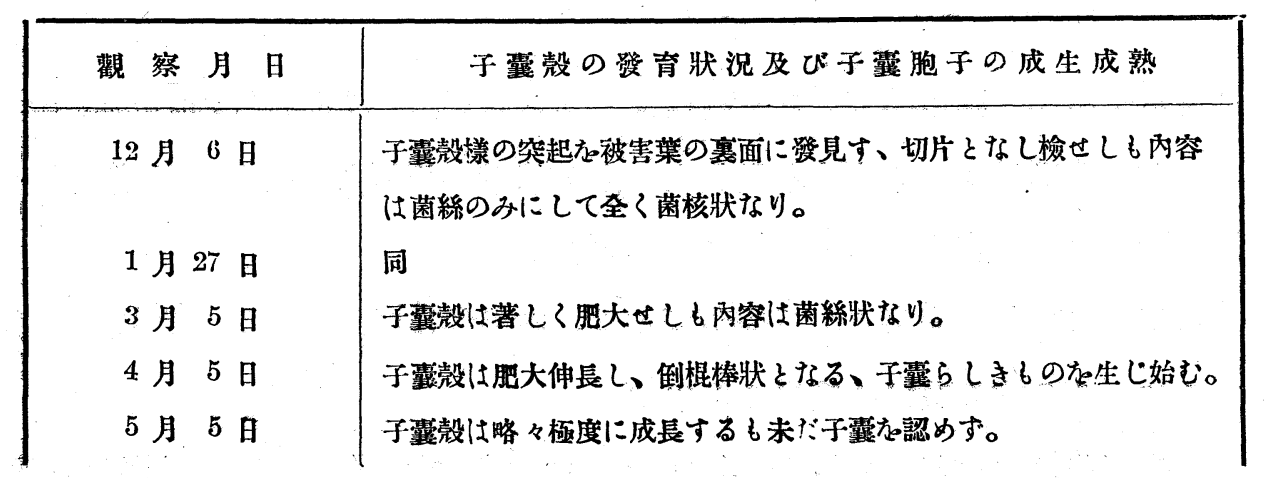




\begin{tabular}{|c|c|}
\hline $\begin{array}{l}6 \text { 月 } 2 \text { 日 } \\
6 \text { 月 } 15 \text { 日 }\end{array}$ & 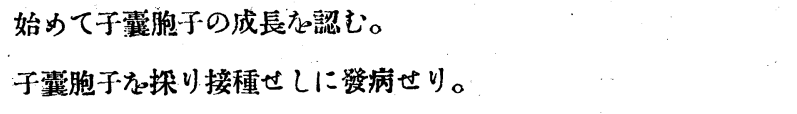 \\
\hline & （II） 1929-1930 年つ観察 \\
\hline 觀 察月 日 & 子囊殼の發䏍狀況及び子囊胞子の成生成熟 \\
\hline 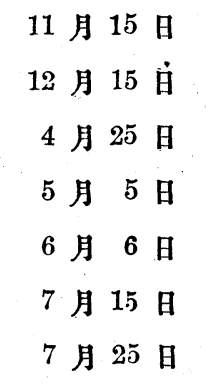 & 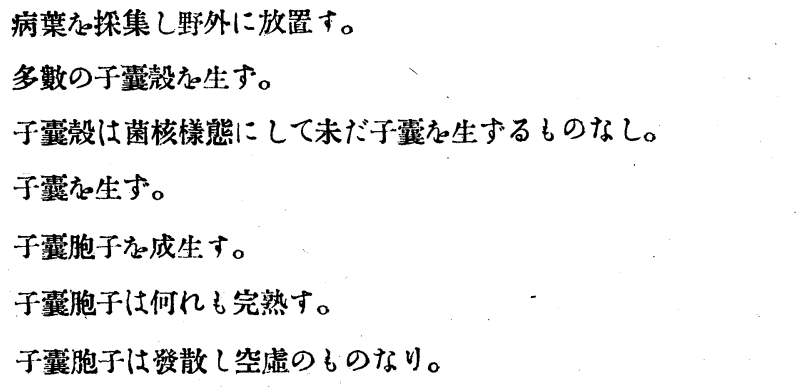 \\
\hline
\end{tabular}

以上二箇年の野外觀察によれば、本菌の子囊殼は六・七箇月の長日月を費して 完熟するものにして、子囊胞子が天然に飛散するは七月以降なるを知れら。

\section{C. 分生胞子の生存力}

天然に於て生せし分生胞子を棌探集し、野外及び室內に放置し、二箇年間？ の生存力を检したるに多くは四月迄に死隇し稀に五月上旬迄生存するものあ ๖、その生存期間は最長大體五月初旬、普通四月上旬迄なるを知れり。 以上の如くなるを以て本菌の初期傳染は專ら子囊胞子に起因すべし。

\section{九 摘 要}

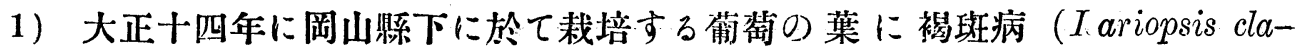
vispora）に酷似する新病害を發見し、之が病徵、病原菌の形態、所屬、寄生 性、生活史及び寄主體侵入法等につき䂰究せり。

2) 本病は未記載の病害にして褐斑病さは、肉眼的に識别するここを得るのみ ならず、その病原菌は全然異るものなり。

3）本病原菌は之を新種飞認め Acrospermum vitico'a Ikata なる新名を附せ 
bo

4) 本病菌は分生胞子時代さ子囊胞子時代とを有す、前者は樹上の病葉の斑點 の裹面に之を生じ、後者は落葉乾枯せし葉の病斑の表面に之を生ず。

5) 本菌はアメリカ葡萄の葉を侵害するる歐洲種を侵害するここなし。

6) 本菌の適溫は $20-25^{\circ} \mathrm{C}$ なるが如し。

7）本菌の分生胞子及び子囊胞子の發芽管は葡背葉の氣孔より侵入するものな b.

8）本病の初期傳染は子囊胞子のみによるへし。

圖版說明

第一圖 版
A キャン心゙ルスアーリ種の葉に於ける病狀
B キャンベルスアーリ種の病葉が樹下の地面に落葉し翌年春期に至り、その裏面に子囊殼が生ぜる 状、黑色刺狀の物は師ちそれなり。
C 成熟せる子囊殼の形狀(約 100 倍)

\section{第二圖版}
A 未熟なる子霍殼の緥斷面を示寸(粅 100 倍)
B 子囊胞子(粅 500 倍)
C. 病原菌の侵入法(約 500 倍)

分生胞子ふ、キャンベルスアーリ種の葉裹に接種し三日の後固定せし標本にて嬐出す、中央緥㴊

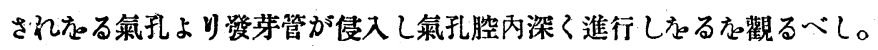

D同（粷 600 倍カメシにて轉窝）

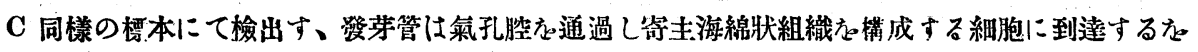
觀る。

\section{Résumś}

1. The present paper deals with the studies carried out by the writers on some morphological, physiological and pathological characters of the new fungus which causes a leaf-blight of grape-vines. 
2. On culture media such as standard agar, potato sucrose agar and grapeleaf decoction agar, the fungus grows well, constantly producing conidia though perithecia have never been found.

3. By arti cial inoculations with conidia or ascospores infection is obtained. on American varieties (Vitis laburuscana; but not on European varieties ( $($ itis vinifera).

4. Incubation period of the fungus is about 15 to 20 days when inoculated with ascospores and about 15 to 16 days in the case of conidia.

5. Infection only results when the spores are inoculated under the surface of the leaves.

6. It is proved by cytological investigation that the penetration of the fungus is through stomata by means of germ-tubes.

7. The primary infection may bə established by ascospores only, because the longibility of conidia is at most to May.

8. The formation of perithecia begins in November, taking a form first like a sclerotial body and ascospores are formed in Jnne to July.

9. The optimum growth of the fungus is at $20-25^{\circ} \mathrm{C}$.

10. The disease and its causal fungus are briefly described as follows:

In August 1925, a new leaf-blight of grape-vines was observed by one of the writers in vicinity of Okayama. From the end of July to November the disease is noticeable by cuusing concentric large brown spots on the leaves and shedding the leaves prematurely. As the symptom of the disease very much resembles that of well known leaf-blight caused by Isariopsis clavispora (B. et C.) Sacc., so the disease has often been confounded by viticulturists. But the disease in question is easily distinguishable from the latter by the concentric spots, giving the lesions a 'target-board' effect. 
The causal fungus of the disease is hitherto undescribed, therefore the name 'Acrospcrmum viticola' is proposed for the fungus.

Acrozpermun vilicola Ikata n. sp.

Peritheria stage: Perithethia usially develop under the surface of the fallen leaves, at frist as small black dots, later very conspicuous thorn-like appearance. They are scattered, free, superficial ; lavceolate or clavate, somewhat compressed; black in color ; leathery thick-walled; measuring 90C-2100 $\mu$ in length, $195-445 \mu$ in diameter. Asci are hyaline long, cylindrical; thinwalled with round apex; $225-413 \mu$ long, 2.5-3.5 $\mu$ wide; 8 spored without paraphyees. Ascospores are hyaline, very slender, long filamentous, nonseptate ; measuring $152-180 \mu$ long, $1-2 \mu$ wide, $189.5 \times 1.5 \mu$ in average.

Conidial stage: Conidiophores singly arise from creeping mycelia grown under the surface of the diseased leaves and not from mycelia in the host tissue directly. After the primary conidiophores grow up in some length, their apex swells like a head where conidia set on abundantly; the secon lary conidiophores then arising from the basal part of the head also form heads and conidia. Thus the formation of conidia is repeated in two to several times. Conidiophores are multiseptose, usually simple, rarely branched, light brownish yellow in color, 1-э septate, very variable in length from 30 to $300 \mu$ and 3 to $4 \mu$ in width including secondary conidiophores. The primary and the secondary conidiophores are 1-3 septate, 25-90 $\mu$ long and 3-4 4 wide with many conidia on the head. Conidia are verticillate, cylindrical or ellipsoid. The attached parts of sterigmate are tapering and their apposite ends are round, somewhat curved to one side. They are hyaline, non-septaté when young, light yellow grey, 3-4, usually 1-2 septate when matured, 7.5- 
16.3 $\mu$ long and $2 . C-6.0 \mu$ wide,averaging $10.8 \times 2.7 \mu$ in size.

This conidial stage belongs to the genus Spondylo ladium or Acroth ciun.

Habitat: The fungus is collected in Okayama in September, 1925 and Fukuoka in Novernber 1929 by S. Ikata and in Chiba in 1914 by S. Hori.

\section{Phytopathological laborat ry of}

Okayama Agricultural Experiment

Station, Okayama, Japan. 


\section{第一圖版}

A
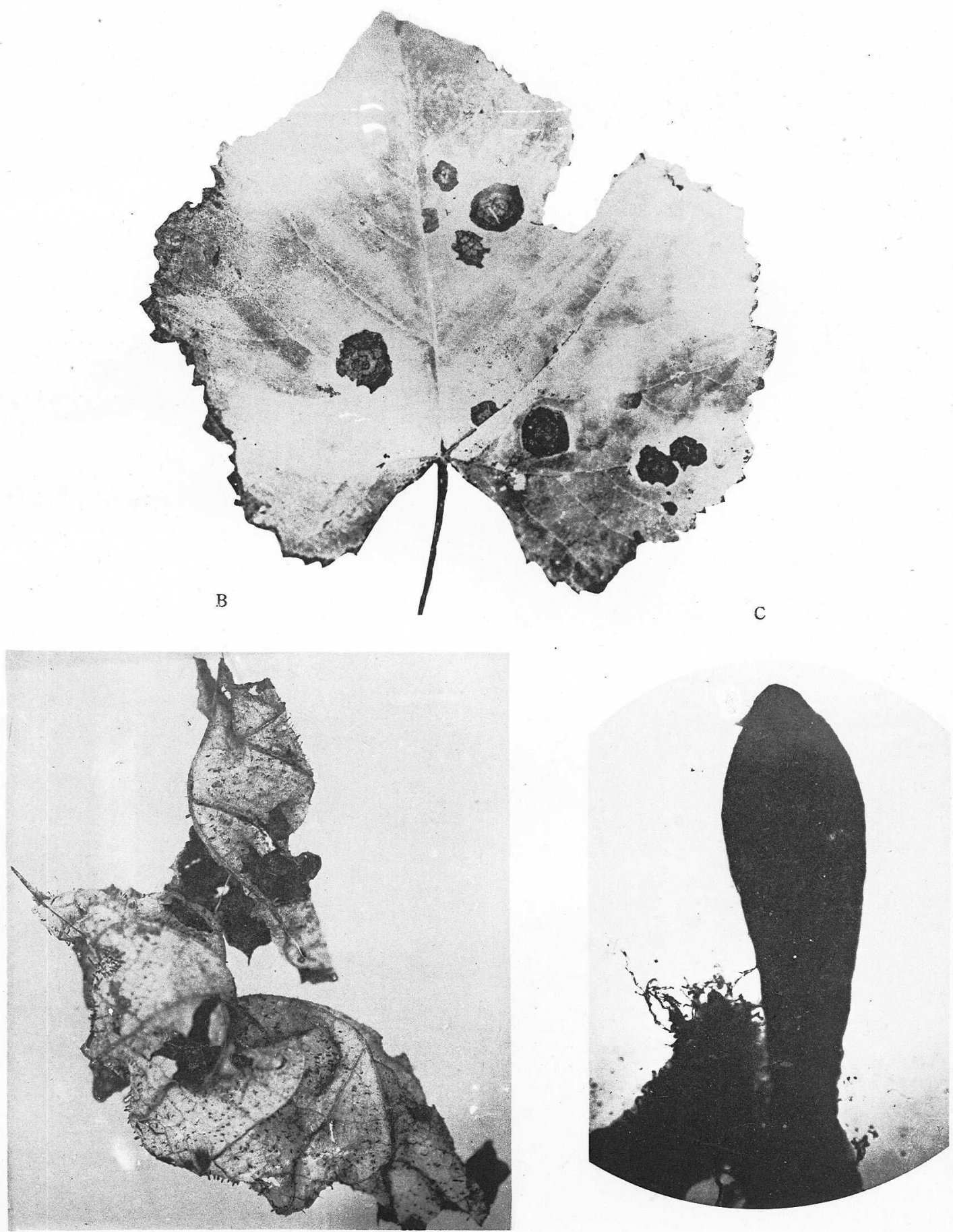

S, Ikata Phot. 


\section{第二圖版}

A

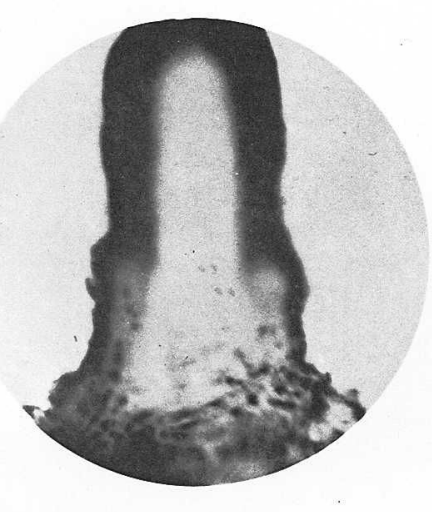

B

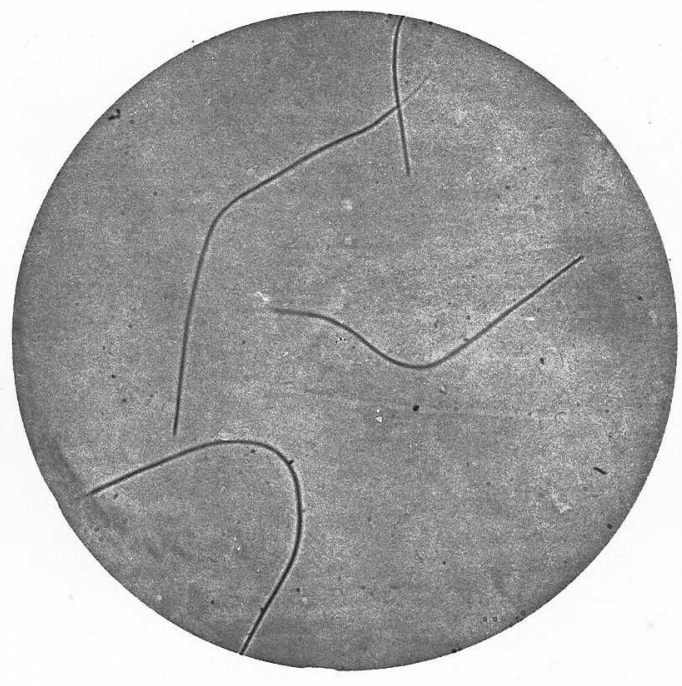

D

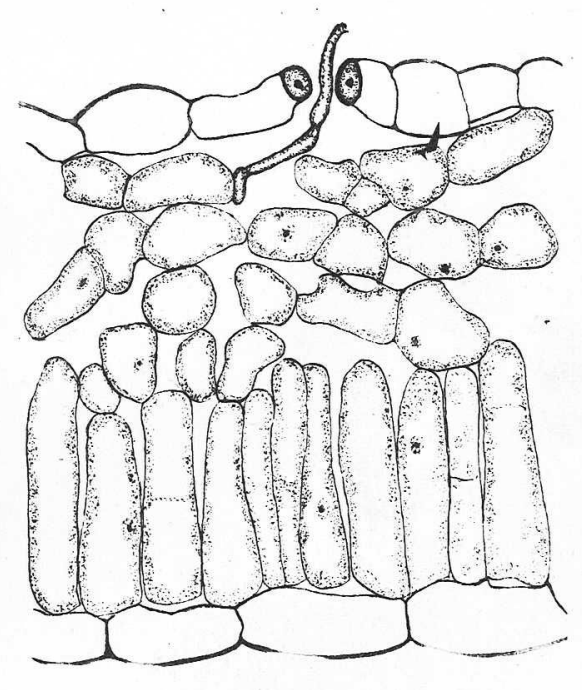

S, Ikata Phot. 